\title{
Molecular and enzymological evidence for two classes of fumarase in Bacillus stearothermophilus (var. non-diastaticus)
}

\author{
Susan K. Reaney, ${ }^{1}$ Stephen J. Bungard ${ }^{2}$ and John R. Guest ${ }^{1 *}$ \\ 'The Krebs Institute for Biomolecular Research, Departmentof Molecular Biology and Biotechnology, \\ University of Sheffield, PO Box 594, Firth Court, Western Bank, Sheffield S10 2UH, UK \\ ${ }^{2}$ ICI Bio Products \& Fine Chemicals, PO Box 1, Billingham, Cleveland TS23 1LB, UK
}

(Received 13 August 1992; revised 14 October 1992; accepted 19 October 1992)

\begin{abstract}
The gene (fum $A_{B s}$ ) encoding an oxygen-labile fumarase of Bacillus stearothermophilus has been cloned and sequenced. The structural gene (1542 bp) encodes a product $\left(\mathrm{FumA}_{\mathrm{Bst}}\right)$ of $M_{\mathrm{r}} 56788$ containing 514 amino acid residues. The amino acid sequence is $23 \%$ identical (37\% similar) to FumA and FumB, the labile [4Fe-4S]containing fumarases (Class I enzymes) of Escherichia coli. It exhibits no significant similarity to FumC and CitG, the stable fumarases (Class II enzymes) of $E$. coli and Bacillus subtilis (respectively). Enzymological studies indicated that Fum $A_{\mathrm{Bst}}$ resembles the iron-sulphur-containing fumarases in being dimeric $\left(\boldsymbol{M}_{\mathrm{r}} 2 \times 58500\right)$, oxygen labile and partially reactivated by $\mathrm{Fe}^{2+}$ plus DTT. The fum $A_{B s t}$ gene is the first gene encoding a Class I fumarase to be characterized in any organism other than $E$. coli. Enzymological and DNA-hybridization studies further indicated that $B$. stearothermophilus resembles $E$. coli in containing an oxygen-stable fumarase (Class II enzyme). Sequence comparisons revealed significant similarities between the Class I fumarases and the products of adjacent open-reading frames (orf $Z 1$ and orf $Z 2$ ) located upstream of the macromolecular synthesis operon (rps $U-d n a G-r p o D$ ) at 67 min in the E.coli linkage map. Located downstream of fum $A_{B s t}$, there is an unidentified gene (orf2), which is homologous to the rhizobial nodB genes involved in the initiation of root nodule formation.
\end{abstract}

\section{Introduction}

Fumarase (fumarate hydratase: EC 4.2.1.2) catalyses the interconversion of fumarate and L-malate. It functions in the citric acid cycle during aerobic metabolism and in the reductive pathway of the branched form of the citric acid cycle which provides fumarate as an anaerobic electron acceptor during anaerobic metabolism (Guest $e t$ al., 1990).

Two distinct classes of fumarase have been discovered, primarily by cloning and sequencing the fumarase genes of Escherichia coli K12 (Guest \& Roberts, 1983; Miles \& Guest, 1984; Guest et al., 1985; Woods et al., 1986, 1988 a; Bell et al., 1989). This organism contains at least three fumarase genes: fum $A$ and $f u m B$ encoding two similar Class I enzymes, designated FumA and FumB; and $f u m C$, encoding the unrelated Class II enzyme, designated FumC.

* Author for correspondence. Tel. (0742) 768555 ext. 4406; fax (0742) 728697; e-mail MI1JRG @UK.AC.SHEFFIELD.PRIMEA.

The nucleotide sequence data reported in this paper have been submitted to Genbank and assigned the accession number L05611.
FumA and FumB (Class I) are oxygen-labile, ironsulphur-containing homodimeric enzymes (subunit $M_{\mathrm{r}}$ 60000) exhibiting $90 \%$ sequence identity (Bell et al., 1989). Aerobically inactivated FumA can be reactivated by anaerobic incubation with $\mathrm{Fe}^{2+}$ and thiols (Yumoto \& Tokushige, 1988; Flint et al., 1989; Ueda et al., 1991). Recent EPR spectroscopy has shown that FumA resembles aconitase in containing a $[3 \mathrm{Fe}-4 \mathrm{~S}]$ cluster which is converted to a [4Fe-4S] cluster upon activation (Ueda et al., 1991; Flint et al., 1989, 1992). Other Class I fumarases include the immunologically cross-reacting and highly unstable enzyme of Euglena gracilis (Shibata et al., 1985; Woods et al., 1988a) and the oxygen-labile fumarase detected in Bradyrhizobium japonicum (Acuña et al., 1991). In addition, these enzymes may belong to a wider group of hydratases and other enzymes which contain $\mathrm{Fe}-\mathrm{S}$ centres but do not catalyse redox-reactions e.g. aconitase, $\mathbf{L}(+)$-tartrate dehydratase, maleate dehydratase, L-serine dehydratase, lactyl-CoA dehydratase, 2-hydroxyglutaryl-CoA dehydratase, dihydroxyacid dehydratase, DNA endonuclease III and glutamine PRPP amidotransferase (Switzer, 1989; Cammack, 1991; Buckel, 1992).

In contrast, FumC (Class II) is a stable homotetrameric 
enzyme (subunit $M_{\mathrm{r}} 50000$ ) which is related to the products of the citG gene of Bacillus subtilis (Moir et al., 1984; Miles \& Guest, 1985), the FUMI gene of Saccharomyces cerevisiae (Wu \& Tzagoloff, 1987) and the fumC gene of Bradyrhizobium japonicum (Acuña et al., 1991), and to the mammalian mitochondrial fumarases (Kinsella \& Doonan, 1986; Suzuki et al., 1989; Sachettini et al., 1988). The Class II fumarases from diverse sources exhibit a remarkable degree of amino acid sequence conservation (50-65\% identity). It is also clear that the Class II fumarases belong to a family of structurally related homotetrameric enzymes including aspartase, argininosuccinase (Woods et al., 1988b) and adenylosuccinase (He et al., 1992), which are $38 \%, 15 \%$ and $19 \%$ identical to FumC, respectively.

In previous studies with $c i t G$ mutants of $B$. subtilis there was no evidence for multiple fumarases (Rutberg \& Hoch, 1970), suggesting that the obligately aerobic bacilli (Gram-positive) may differ from the facultatively anaerobic enterobacteria (Gram-negative) in containing a single Class II fumarase rather than representatives of both classes. A fumarase gene of B. stearothermophilus was therefore sought for use in amplifying a thermostable and oxygen-insensitive enzyme for structural and mutagenic studies. This paper reports the characterization of a gene $\left(\right.$ fum $A_{B s s}$ ) encoding a Class I (oxygen-labile) fumarase, as well as preliminary evidence for the presence of a Class II fumarase in B. stearothermophilus. An adjacent gene related to the $\operatorname{nod} B$ genes of nodulating bacteria was also characterized, and a novel relationship between the Class I fumarases and a pair of unidentified E. coli genes was detected.

\section{Methods}

Bacterial strains, plasmids and phagemids. The bacterial strains, plasmids and phagemids are listed in Table 1. E. coli JH400 lacks all three fum genes and was used in the cloning and complementation studies; other strains used for the isolation and propagation of phages and phagemids were: C600 (גZAPII derivatives), JMI0I (M13 derivatives), and XL1-Blue (phagemids). The gene bank of $B$. stearothermophilus var. non-diastaticus (DSM 2334) contained products of complete and partial EcoRI digestion ( 2 to $9 \mathrm{~kb}$ ) ligated in the Stratagene vector $\lambda$ ZAPII (Mallinder et al., 1992). Phagemids were excised from $\lambda$ ZAPII derivatives by the in vivo procedure provided by the supplier.

Media and growth conditions. The rich medium used for routine subculture was L-broth. A weak peptone medium (BBL) was used to detect $\lambda$ fum phages as described previously (Guest \& Roberts, 1983). Transformants of $E$. coli JH400 were tested for complementation of the Fum $^{-}$phenotype on plates of citrate-free minimal medium (Cole \& Guest, 1980) containing glucose (11 mM), sodium L-malate $(40 \mathrm{mM})$ or sodium fumarate $(40 \mathrm{mM})$ as sole carbon source and supplemented with methionine $\left(40 \mu \mathrm{g} \mathrm{ml}^{-1}\right)$ and ampicillin $\left(100 \mu \mathrm{g} \mathrm{ml}^{-1}\right)$ as required. All strains were grown aerobically at either $30^{\circ} \mathrm{C}$ ( $\lambda$-infected cultures), $55^{\circ} \mathrm{C}$ (thermophiles) or $37^{\circ} \mathrm{C}$ (other strains).

Table 1. Bacterial strains, phagemids and plasmids

\begin{tabular}{|c|c|c|}
\hline $\begin{array}{l}\text { Bacteria, phagemids } \\
\text { and plasmids }\end{array}$ & Relevant genotype or phenotype & Source or reference \\
\hline \multicolumn{3}{|l|}{ Bacterium } \\
\hline \multicolumn{3}{|l|}{ E. coli } \\
\hline W3110 & Wild-type & \\
\hline JM101 & $\Delta($ lac-proAB $) \mathrm{F}^{\prime}\left(\right.$ traD36 proA $A^{+} B^{+}$lacI $\left.^{\mathrm{q}} Z \Delta M 15\right)$ & Messing (1983) \\
\hline JH400 & $\begin{array}{l}\Delta(\text { dgs-fumCA-man } A) D 1 \Delta(\text { mel-fumB }) z d g-232:: \operatorname{Tn} 10 \\
\text { met Bl spoTl relA }\end{array}$ & Henson et al. (1987) \\
\hline C600 & thr leuB6 thi-1 supE44 tonA21 lac YI & Guest \& Roberts (1983) \\
\hline XL1-Blue & 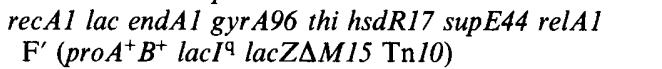 & Bullock et al. (1987) \\
\hline $\begin{array}{l}\text { B. stearothermophilus } \\
\text { var. non-diastaticus } \\
\text { DSM } 2334\end{array}$ & $\mathrm{Bio}^{-}$ & Mallinder et al. (1992) \\
\hline $\begin{array}{l}\text { B. stearothermophilus } \\
\text { NRRL } 1174\end{array}$ & Undefined auxotrophy & Liao etal. (1986) \\
\hline $\begin{array}{l}\text { B. subtilis } 1604 \\
\text { B. caldotenax DSM } 406\end{array}$ & $\operatorname{trpC} 2$ & $\begin{array}{l}\text { Moir et al. }(1979) \\
\text { Sharp et al. }(1986)\end{array}$ \\
\hline \multicolumn{3}{|l|}{ Phagemid } \\
\hline $\begin{array}{l}\text { pBluescript } \\
\text { pGS507 }\end{array}$ & $\mathrm{Ap}^{\mathrm{R}}$ & Stratagene \\
\hline $\left.\begin{array}{l}\text { pGS509 } \\
\text { pGS511 }\end{array}\right\}$ & pBluescript derivative, $\mathrm{Ap}^{\mathrm{R}}$ & This study \\
\hline \multicolumn{3}{|l|}{ Plasmid } \\
\hline $\begin{array}{l}\text { pGS96 } \\
\text { pGS54 } \\
\text { pGS210 }\end{array}$ & $\begin{array}{l}\text { cit } G_{B s u} \text { in pHV33, } \mathrm{Ap}^{\mathrm{R}} \\
\text { fumA }^{\mathrm{R}} C_{E c o} \text { in } \mathrm{pBR} 322, \mathrm{Ap}^{\mathrm{R}} \\
\text { fum }_{E c o} \text { in } \mathrm{pUC12}, \mathrm{Ap}^{\mathrm{R}}\end{array}$ & $\begin{array}{l}\text { Moir etal. (1984) } \\
\text { Guest \& Roberts (1983) } \\
\text { Woods \& Guest (1987) }\end{array}$ \\
\hline
\end{tabular}


Enzymology. Cultures were grown in L-broth to early stationary phase, harvested, and disrupted by ultrasonic treatment ( 6 periods of $30 \mathrm{~s}$, frequency $10 \mathrm{MHz}$, at $0{ }^{\circ} \mathrm{C}$ with $30 \mathrm{~s}$ intervals) in $40 \mathrm{~mm}$-potassium phosphate buffer, $\mathrm{pH} 7 \cdot 8$. Cell debris was removed by centrifuging at $11600 \mathrm{~g}$ for $30 \mathrm{~min}$ and supernatants (cell-free extracts) were assayed the same day for fumarase by following the formation of fumarate from L-malate at $240 \mathrm{~nm}$ and at $55^{\circ} \mathrm{C}$ (unless otherwise stated): activities are expressed in units ( $\mu \mathrm{mol}$ fumarate formed $\mathrm{min}^{-1}$ ) per $\mathrm{mg}$ protein using an extinction coefficient of $2.441 \mathrm{mmol}^{-1} \mathrm{~cm}^{-1}$ at $240 \mathrm{~nm}$ (Hill \& Bradshaw, 1969). For heat treatments, samples $(100 \mu l)$ of the extracts were incubated at $50^{\circ} \mathrm{C}$ for specified times either in air (aerobic samples) or degassed and held in an anaerobic cabinet $\left(0^{\circ} \mathrm{C}\right.$ for $\left.30 \mathrm{~min}\right)$ under an atmosphere of $\mathrm{H}_{2} / \mathrm{N}_{2} / \mathrm{CO}_{2}(5: 85: 10$, by vol.) and sealed prior to incubation (anaerobic samples); the residual activities were assayed under aerobic conditions. Protein was assayed according to Bradford (1976) using Bio-Rad reagent. Native $M_{\mathrm{r}}$ values were determined by gel-filtration with crude extracts $(0.5 \mathrm{ml})$ of $B$. stearothermophilus (1.2 units) and plasmid (pGS509)-amplified JH400 (46 units), using a Pharmacia XK26 column containing a Sephacryl 200 HR matrix, equilibrated and eluted $\left(1.5 \mathrm{ml} \mathrm{min}^{-1}\right)$ under aerobic conditions with $40 \mathrm{~mm}$-potassium phosphate buffer, $\mathrm{pH} 7.8$. The column was calibrated using standard proteins $\left(M_{\mathrm{r}}\right): \beta$-amylase (200000); alcohol dehydrogenase (150000); carbonic anhydrase (29000); cytochrome $c(12300)$. Fractions $(5 \mathrm{ml})$ were collected and assayed for fumarase activity. SDS-PAGE was performed by the method of Laemmli (1970).
DNA manipulation and sequencing strategy. Standard methods were used for cloning, restriction endonuclease digestion, plasmid isolation and transformation (Sambrook et al., 1989). The sequencing strategy involved cloning the $0.9 \mathrm{~kb}, 0.6 \mathrm{~kb}$ and $1.4 \mathrm{~kb} E c o$ RI fragments of pGS509 into the corresponding site of M13mpl 8 and sequencing with universal primer (Fig. 1). Deleting HindIII and SalI fragments from appropriate restriction fragment derivatives allowed further sequence to be obtained. Synthetic primers were used to complete the sequence with pGS509 as the double-stranded template. Single-stranded and double-stranded templates were sequenced by the dideoxy chain termination method, using Sequenase (Sequenase protocols, United States Biologicals). Oligonucleotides were synthesized using an Applied Biosystems 381 DNA synthesizer.

Nucleotide sequences were compiled and analysed using the Staden computer programs (Staden, 1980, 1982, 1984; Staden \& McLachlan, 1982). Multiple sequence alignments were generated initially by the CLUSTAL microcomputer programs (Higgins \& Sharp, 1988, 1989) and refined by DIAGON and visual inspection. For other computer analyses, including database searching with TFASTA and FASTA, the University of Wisconsin Genetics Computer Group (UWGCG) package (Devereux et al., 1984) was accessed through the SEQNET VAX 3600 on node DLVH (Daresbury Laboratory, Warrington, UK).

In vitro transcription-translation and Southern blotting. The prokaryotic DNA-directed translation kit containing an $E$. coli S-30 extract (Amersham) was used with intact phagemid DNA and $L-\left[{ }^{35} \mathrm{~S}\right]-$

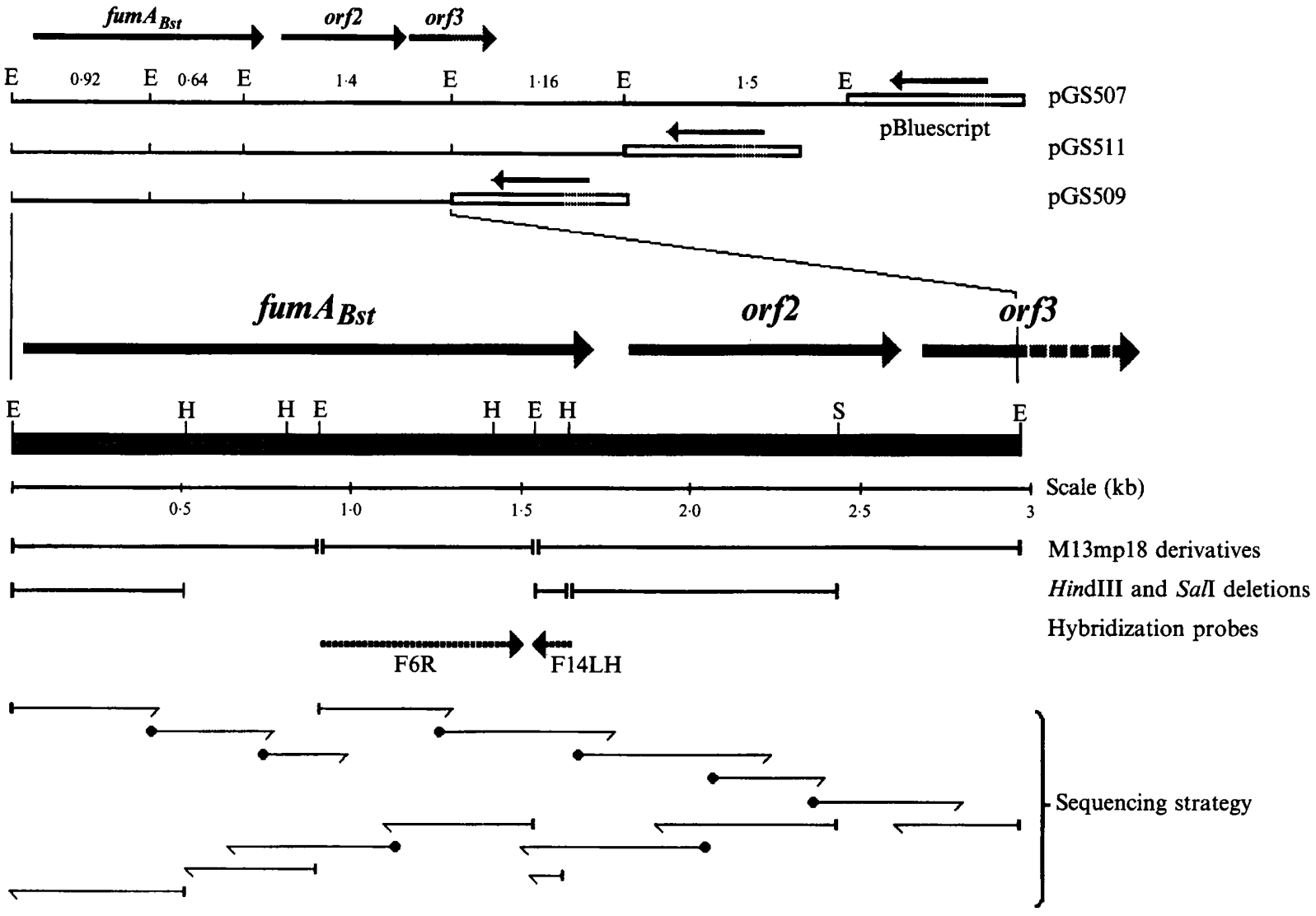

Fig. 1. Restriction maps of phagemids (pGS507, pGS509 and pGS511) containing the fum $A_{B s t}$ gene and summary of sequencing strategy. The unlabelled arrows denote the polarity of $l a c Z$ transcription in pBluescript. The enlarged region shows the $3 \mathrm{~kb}$ fragment cloned in pGS509, the subfragments cloned in M13mpl8 and the HindIII or Sall deletion derivatives. The positions and polarities of coding regions are indicated by filled arrows and the hybridization probes by broken arrows. In the sequencing strategy, thin arrows denote directions and extents of sequence obtained from M13 derivatives or double stranded pGS509 using universal primer ( $(\mathrm{)})$ or specifically designed primers $(\diamond)$. Relevant restriction sites are as follows: E, EcoRI; H, HindIII; and S, SalI. 
methionine, according to the manufacturer's instructions. For Southern blotting, bacterial DNA was digested with EcoRI, fractionated by electrophoresis (0.8\% agarose, Tris/acetate/EDTA gel) and transferred to nitrocellulose membrane (Sambrook et al., 1989). The blots were hybridized for $18 \mathrm{~h}$ at $60^{\circ} \mathrm{C}$ with $6 \times \mathrm{SSC}$ (low stringency) and washed $(2 \times 15 \mathrm{~min})$ with $2 \times \mathrm{SSC}$ plus $0.1 \%$ SDS $(\mathrm{w} / \mathrm{v})$ at $65^{\circ} \mathrm{C}$ [ $2 \times \mathrm{SSC}$ contains $\mathrm{NaCl}(0 \cdot 3 \mathrm{M})$ and sodium citrate $(0.03 \mathrm{M}, \mathrm{pH} 7)]$. Probes containing specific regions of four fumarase genes were derived from M13 templates by primer-extension labelling with digoxygenin (Boehringer Mannheim) : citG, $0.8 \mathrm{~kb}$ Bcll-HindIII fragment of pGS96 in M13mp10 (Miles \& Guest, 1985); fumC, $0.8 \mathrm{~kb}$ XhoI-Bcll fragment in M13mp10 (Woods et al., 1986); fumA, $0.7 \mathrm{~kb}$ PstI-BclI fragment in M13mp8 (Miles \& Guest, 1984); fum $A_{B s t}$, M13mp18 derivatives FI4LH and F6R, see Fig. 1. The corresponding restriction fragments were isolated by electrophoresis in a low melting point agarose gel for use in hybridization and detection was according to the manufacturer's instructions.

Materials. Restriction endonucleases and DNA ligase were purchased from Northumbria Biologicals, the Sequenase kit was from Cambridge Bioscience, the non-radioactive (digoxygenin) DNA- labelling and detection kit was from Boehringer Mannheim and the prokaryotic DNA-directed translation kit, L- $\left[{ }^{35} \mathrm{~S}\right]$ methionine $(>37$ TBq $\mathrm{mmol}^{-1}$ ) and $\left[\alpha_{-}{ }^{35}\right.$ S $]$ thio-dATP ( $>37 \mathrm{TBq} \mathrm{mmol}^{-1}$ ) were purchased from Amersham. $M_{\mathrm{r}}$ markers for SDS-PAGE and gel-filtration were obtained from BDH and Sigma, respectively.

\section{Results and Discussion}

\section{Cloning a fumarase gene of $B$. stearothermophilus}

A $\lambda$ ZAPII gene bank of $B$. stearothermophilus was screened for $\lambda$ fum phages by their ability to produce transduction plaques on $E$. coli $\mathrm{JH} 400(\Delta$ fum $A C \Delta$ fumB $)$. Two distinct and stably inherited plaque morphologies were detected. Those designated smoke rings were turbid rings of 3-6 $\mathrm{mm}$ diameter having clear centres that eventually filled with diffuse micro-colonies, whereas the galaxies consisted of compact clusters of micro-colonies.
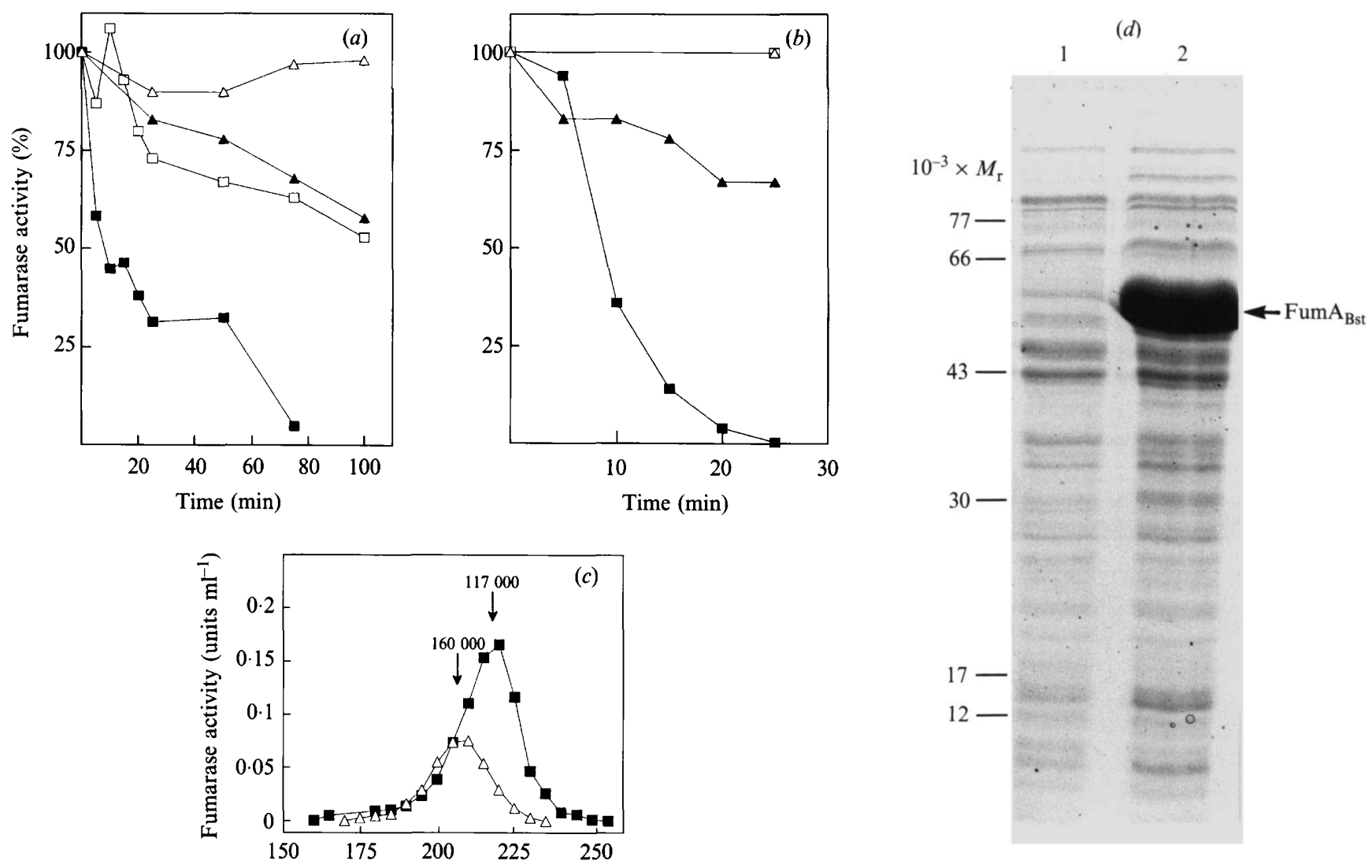

Fig. 2 Aerobic and ammonium persulphate inactivation and molecular properties of $\operatorname{FumA}_{\mathrm{Bst}} \cdot(a)$ Extracts were incubated aerobically and anaerobically at $50{ }^{\circ} \mathrm{C}$ for different periods prior to assaying for residual fumarase activity (\%). Strains and initial specific activities are: JH400(pGS509), aerobic $(\square)$, anaerobic $(\square), 42 \cdot 3$ units (mg protein) ${ }^{-1} ;$ B. stearothermophilus, aerobic $(\Delta)$, anaerobic $(\triangle), 2 \cdot 2$ units $(\mathrm{mg} \text { protein })^{-1}$. (b) Extracts were treated with ammonium persulphate $(1 \mathrm{~mm})$ at $0{ }^{\circ} \mathrm{C}$ in air and assayed for residual fumarase activity (\%). Strains and initial specific activities are: JH400(pGS509), ammonium-persulphate-treated ( $\square$ ), untreated ( $\square$ ), $14 \cdot 2$ units $(\mathrm{mg} \text { protein })^{-1} ; B$. stearothermophilus, ammonium-persulphate-treated $(\boldsymbol{\Delta})$, untreated $(\triangle), 1 \cdot 2$ units $(\mathrm{mg} \text { protein })^{-1}$. (c) Gel-filtration profiles for fumarase activities (units $\mathrm{ml}^{-1}$ ) with extracts of JH400(pGS509) ( $\boldsymbol{\square}$ ), and B. stearothermophilus $(\Delta)$ ). The vertical arrows denote $M_{\mathrm{r}}$ deduced from the elution of standard proteins. (d) Coomassie-blue-stained SDS-PAGE gel (15\%) of cell-free extracts of JH400 (lane 1) and JH400(pGS509) (lane 2). FumA $A_{\text {Bst }}$ (arrowed) and the positions of $M_{\mathrm{r}}$ markers are indicated. 
The aetiology of these morphologies is unknown, but neither was exactly like the dense transduction plaques obtained with $\lambda$ fum $A$ and $\lambda f u m B$ or the lysogen-filled plaques obtained with the $B$. subtilis counterpart, $\lambda$ cit $G$ (Guest \& Roberts, 1983; Moir, 1983). This is probably because 2ZAPII contains a ColE1 replicon which would prevent stable prophage integration. Studies with the corresponding lysogens were frustrated by instability and irreproducibility, possibly for the same reason.

The complementing phages were purified, converted to pBluescript phagemids, and studies with double-stranded phagemid DNA from nine independent phages showed that they contain a nested set of three to five EcoRI fragments inserted with the same polarity. Four phagemids (represented by pGS509) contained the common $3 \mathrm{~kb}$ insert consisting of three EcoRI fragments $(0.92,0.64$ and $1.40 \mathrm{~kb})$, whereas three (represented by pGS511) contained an extra $1.16 \mathrm{~kb}$ EcoRI fragment, and two (represented by pGS507) contained a further $1.50 \mathrm{~kb}$ EcoRI fragment (Fig. 1). There was no correlation between plaque morphology and inserted DNA.

\section{Characterization of the phagemid-encoded fumarase}

The fumarase-deficient strain $\mathrm{JH} 400$ grows on malate minimal medium but not with fumarate as the sole carbon source. This nutritional lesion was complemented by transformation with pGS507, pGS509 and pGS511, as with pGS54 (fumAC), pGS96 (citG) and pGS210 (fumC), but not with pBluescript. The fumarase activity [units (mg protein) ${ }^{-1}$ ] in cell-free extracts of JH400 $(0.006)$ was likewise increased in transformants containing pGS507 (45.3), pGS509 (31.8), pGS511 (8.4), pGS54 (91.0), pGS96 (7.4) and pGS210 (40.3). Further studies with JH400(pGS509) indicated that a polypeptide of $M_{\mathrm{r}} 58000$ is amplified to approximately $40 \%$ of soluble cell protein in freshly transformed cells (Fig. 2). In gel-filtration, the fumarase activity eluted with an apparent $M_{\mathrm{r}}$ of 117000 indicating that the enzyme is homodimeric. The fumarase activity was unstable in air and rapidly inactivated by ammonium persulphate (Fig. 2) but the rate of inactivation could be lowered by fumarate $(2 \mathrm{mM})$ and partial reactivation was obtained by incubating with $0.5 \mathrm{mM}-\mathrm{Fe}^{2+}$ plus $50 \mathrm{mM}$-dithiothreitol. These results indicate that the common $3 \mathrm{~kb}$ inserts of pGS507, pGS509 and pGS511 express an oxygen-labile homodimeric (Class I) fumarase, FumA $A_{\text {Bst }}$. When amplified in $E$. coli, the enzyme had a thermostability consistent with its source. The temperature optimum was $55-60^{\circ} \mathrm{C}$ and, when incubated under anaerobic conditions, the half-lives (min) at different temperatures were: $>100\left(50^{\circ} \mathrm{C}\right), 20\left(60^{\circ} \mathrm{C}\right)$ and $<5$

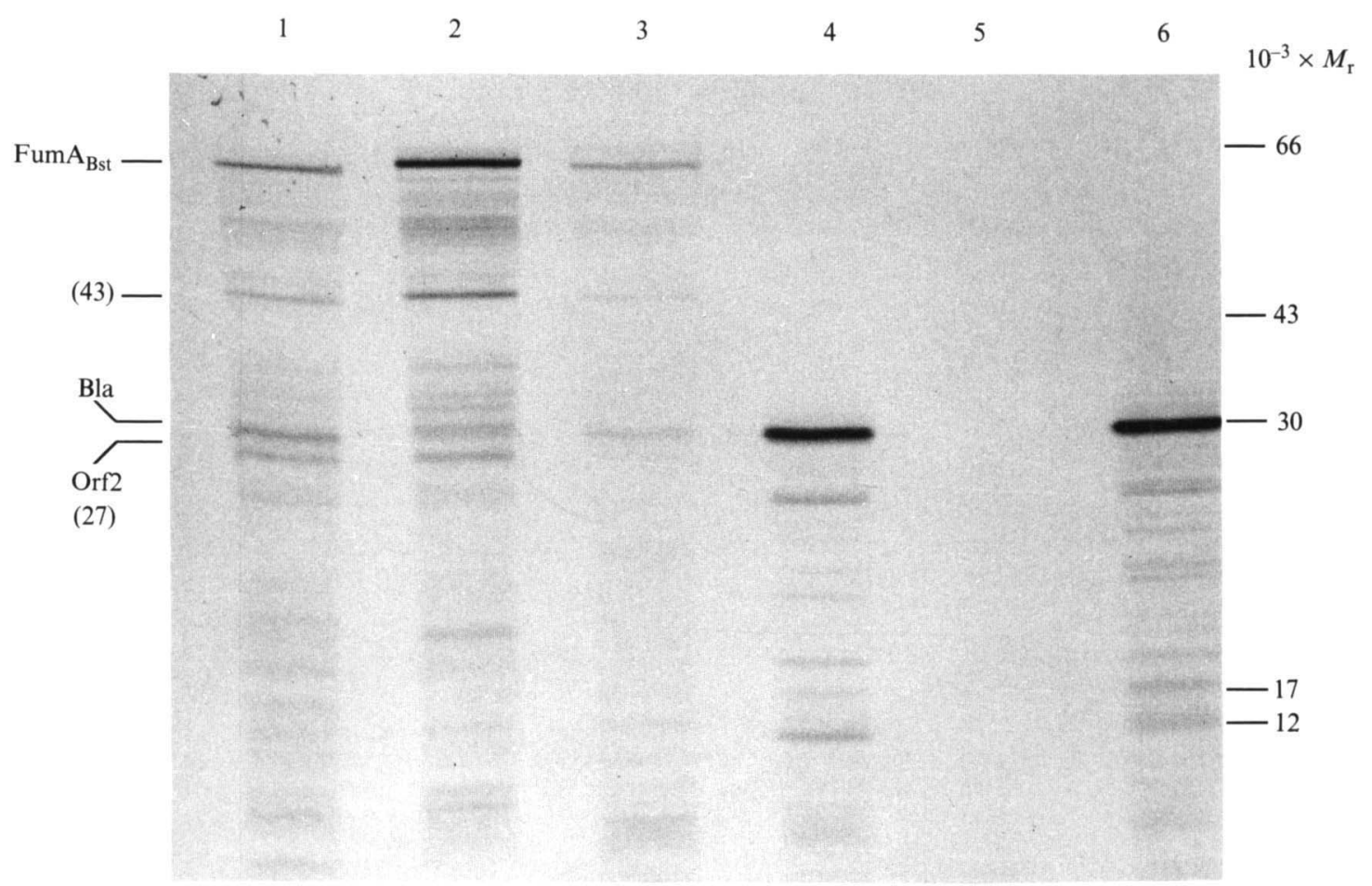

Fig. 3. In vitro transcription-translation analysis. Autoradiogram of ${ }^{35}$ S-labelled polypeptides expressed from pGS507 (lane 1), pGS509 (lane 2), pGS511 (lane 3), pBluescript (lane 4), no DNA (lane 5) and pAT153 (lane 6). Relevant labelled products and the positions of $M_{\mathrm{r}}$ markers are indicated. 
GAATTCGCAAGCTGAATCTTTTTTAACTGCTGCAATGAATGCTGAAACACTTTCCCTATCCCCCTAAAAAAATGATCAGCACGTGAATGC $\begin{array}{llllllllll}\text { ECORI } & 10 & 20 & 30 & 40 & 50 & 60 & 70 & 80 & 90 \\ \text { fumA }\end{array}$

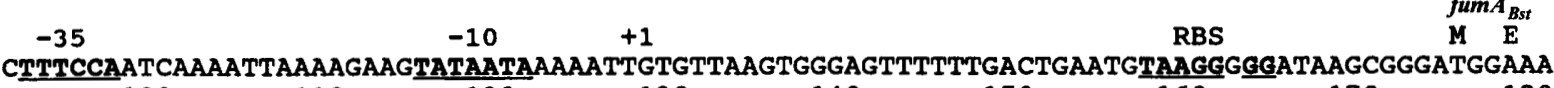
$\begin{array}{llllllll}100 & 110 & 120 & 130 & 140 & 150 & 160 & 170\end{array}$

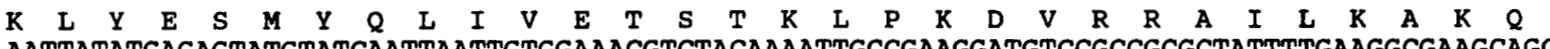

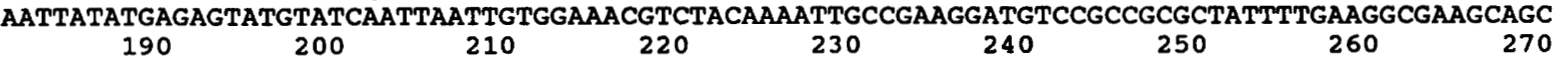

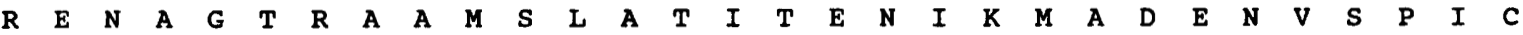

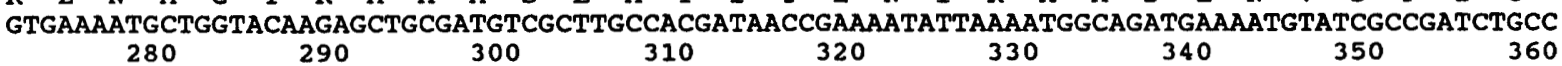

$\begin{array}{lllllllllllllllllllllllllllllll}Q & D & T & G & I & P & T & F & K & I & K & V & P & V & G & I & N & Q & I & Q & I & K & E & T & I & K & K & A & I & A\end{array}$ AAGATACCGGATTGCCGACATTTAAAATTAAAGTGCCAGTCGGTATCAATCAAATTCAAATAAAGGAAACAATAAAAAAAGCGATCGCTC $\begin{array}{lllllllll}370 & 380 & 390 & 400 & 410 & 420 & 430 & 440 & 450\end{array}$

$\begin{array}{lllllllllllllllllllllllllllllll}Q & A & T & K & D & G & K & L & R & P & N & S & V & D & S & L & T & G & E & N & S & G & D & N & L & G & E & G & L & P\end{array}$ AAGCGACGAAGGACGGGAAGCTTCGCCCGAACTCGGTCGATTCACTCACTGGAGAAAATTCCGGCGATAACTTGGGCGAAGGGCTTCCAG

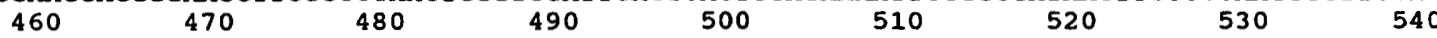

$\begin{array}{llllllllllllllllllllllllllllllll}V & V & K & F & E & Q & \text { W } & E & K & D & Y & M & D & V & R & \text { L } & I & \text { L } & K & G & G & G & C & E & N & K & N & I & Q & Y\end{array}$ TCGTAAAATTTGAACAATGGGAAAAGATTATATGGATGTTCGCTTAATATTAAAAGGCGGCGGCTGCGAAAACAAAAATATTCAATACA $\begin{array}{llllllll}550 & 560 & 570 & 580 & 590 & 600 & 610 & 620\end{array}$

$\begin{array}{lllllllllllllllllllllllllllllll}S & L & P & C & E & L & E & G & L & G & R & A & G & R & D & L & D & G & I & R & K & C & I & L & H & A & V & Y & Q & A\end{array}$ GCCTGCCGTGCGAACTAGAAGGATTGGGAAGAGCCGGCAGAGATTTGGATGGAATCCGCAAATGTATTTTGCATGCGGTATATCAAGCAC

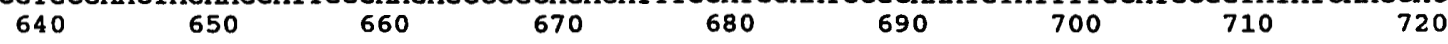

$\begin{array}{llllllllllllllllllllllllllllllllll}Q & G & Q & G & C & S & A & G & F & I & G & V & G & I & G & G & D & R & S & A & G & Y & D & L & A & K & E & Q & L & F\end{array}$ AGGGCCAAGGATGCAGCGCAGGATTCATTGGAGTTGGAATCGGTGGAGACCGTTCAGCGGGGTACGATTTAGCGAAAGAACAATTATTCC

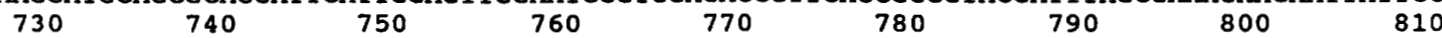

$\begin{array}{lllllllllllllllllllllllllllllll}\mathbf{R} & \mathbf{E} & \mathbf{V} & \mathbf{D} & \mathbf{D} & \mathbf{V} & \mathbf{N} & \mathbf{P} & \mathbf{N} & \mathbf{E} & \mathbf{E} & \mathrm{L} & \mathbf{R} & \mathbf{Q} & \mathbf{L} & \mathbf{E} & \mathbf{E} & \mathbf{Y} & \mathbf{I} & \mathbf{M} & \mathbf{E} & \mathbf{N} & \mathbf{A} & \mathbf{N} & \mathbf{K} & \mathbf{L} & \mathbf{G} & \mathbf{I} & \mathbf{G} & \mathbf{T}\end{array}$ GCGAAGTCGATGACGTAAATCCGAACGAAGAATTGCGGCAATTGGAAGAATATATTATGGAAAATGCAAACAAGCTTGGCATTGGAACGA $\begin{array}{lllllllll}820 & 830 & 840 & 850 & 860 & 870 & 880 & 890 & 900\end{array}$

$\begin{array}{llllllllllllllllllllllllllllllll}M & G & F & G & G & E & T & T & L & L & G & C & K & V & G & A & M & H & R & I & P & A & S & F & F & V & S & V & A & Y\end{array}$

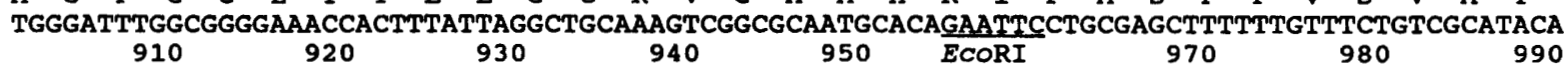

$\begin{array}{llllllllllllllllllllllllllllllll}N & C & W & A & F & R & R & L & G & V & H & I & D & P & N & T & G & E & I & I & K & W & \text { L } & Y & Q & D & G & E & D & V\end{array}$ ACTGCTGGGCATTCCGCCGTTTAGGTGTGCATATCGATCCAAATACGGGTGAAATCATAAAATGGCTTTATCAAGATGGAGAAGATGTTG $\begin{array}{lllllllll}1000 & 1010 & 1020 & 1030 & 1040 & 1050 & 1060 & 1070 & 1080\end{array}$

$\begin{array}{lllllllllllllllllllllllllllllll}D & F & Q & E & N & A & A & Q & E & E & H & L & A & S & T & D & S & E & R & R & V & I & T & L & Q & A & P & I & T & E\end{array}$ ATTTTCAAGAAAATGCTGCACAAGAAGAACATTTAGCATCAACGGACTCTGAAAGACGTGTCATCACGCTGCAAGCGCCAATTACAGAAG $\begin{array}{lllllllll}1090 & 1100 & 1110 & 1120 & 1130 & 1140 & 1150 & 1160 & 1170\end{array}$

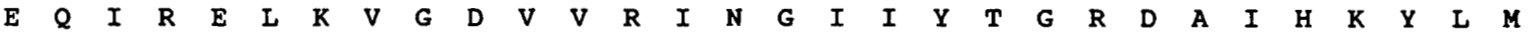
AACAAATCCGCGAGCTGAAAGTCGGCGACGTTGTTCGCATCAACGGAATCATTTACACAGGAAGGGATGCCATCCATAAATATTTAATGG $\begin{array}{llllllll}1180 & 1190 & 1200 & 1210 & 1220 & 1230 & 1240 & 1250\end{array}$

$\begin{array}{llllllllllllllllllllllllllllllll}D & H & D & A & P & V & D & L & N & G & Q & I & I & Y & H & C & G & P & V & M & L & K & D & E & N & G & N & W & E & V\end{array}$ ATCATGATGCGCCGGTTGATTTAAACGGTCAAATTATTTACCACTGCGGACCTGTCATGTTAAAAGATGAAAACGGCAATTGGGAAGTGA $\begin{array}{lllllllll}1270 & 1280 & 1290 & 1300 & 1310 & 1320 & 1330 & 1340 & 1350\end{array}$

$\begin{array}{llllllllllllllllllllllllllllllll}K & A & A & G & P & T & T & S & I & R & E & E & P & Y & Q & G & D & I & M & K & K & F & G & I & R & A & V & M & G & K\end{array}$ AAGCGGCCGGGCCGACCACTTCCATTCGCGAAGAGCCTTATCAAGGGGATATTATGAAAAAATTTGGCATCCGTGCGGTAATGGGCAAAG $\begin{array}{lllllllll}1360 & 1370 & 1380 & 1390 & 1400 & 1410 & 1420 & 1430 & 1440\end{array}$

$\begin{array}{lllllllllllllllllllllllllllllllll}G & G & M & G & Q & K & T & \text { L } & Q & \text { A } & \text { L } & K & \text { E } & \text { H } & G & G & \text { V } & \text { Y } & \text { L } & \text { N } & \text { A } & \text { I } & G & G & A & A & Q & Y & Y & A\end{array}$ GCGGCATGGGGCAAAAAACGCTGCAAGCTTTAAAAGAGCATGGCGGAGTATACTTGAATGCGATTGGCGGTGCTGCTCAATATTATGCGG $\begin{array}{lllllllll}1450 & 1460 & 1470 & 1480 & 1490 & 1500 & 1510 & 1520 & 1530\end{array}$

$\begin{array}{llllllllllllllllllllllllllllll}D & C & I & E & A & V & E & G & V & D & L & L & E & F & G & I & P & E & A & M & W & H & L & R & V & K & D & F & T & A\end{array}$ ATTGCATCGAAGCGGTTGAAGGTGTTGACTTGCTGGAGTTTGGAATTCCAGAAGCTATGTGGCATTTGCGCGTAAAAGACTTCACGGCCG $\begin{array}{lllllllll}1540 & 1550 & 1560 & 1570 & \text { ECORI } & 1590 & 1600 & 1610 & 1620\end{array}$

$\begin{array}{llllllllllllllllllllllllllllll}V & V & T & M & D & S & H & G & N & S & \text { L } & \text { H } & \text { E } & \text { D } & \text { I } & \text { E } & \text { K } & \text { S } & \text { S } & \text { L } & \text { E } & \text { K } & \text { L } & \text { S } & \text { Q } & \text { F } & \text { K } & \text { E } & \text { P } & \text { V }\end{array}$ TTGTCACAATGGATTCACACGGCAACAGCCTGCATGAAGACATTGAAAAATCGTCATTAGAAAAGCTTTCTCAATTTAAAGAGCCGGTAT

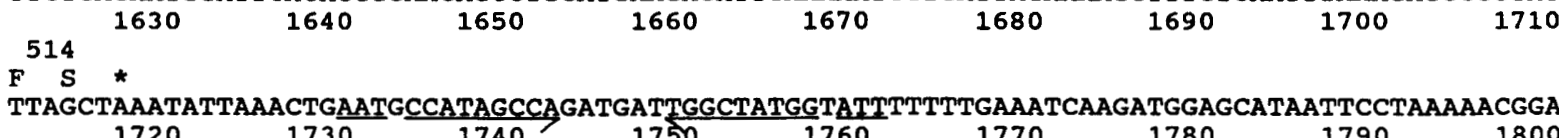

Fig. 4. For legend see facing page. 


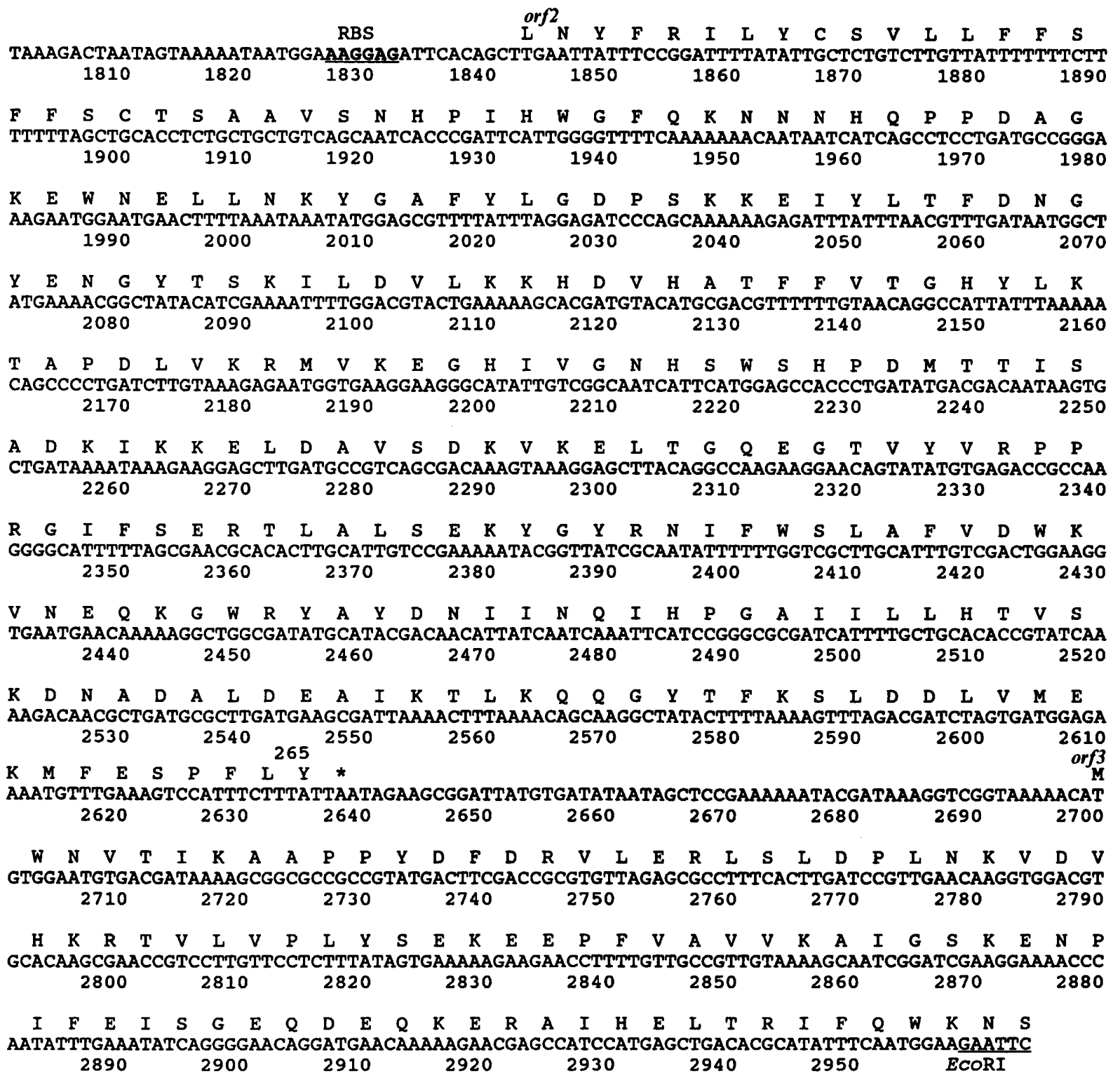

Fig. 4. Nucleotide sequence of the fum $A_{B s t}$, orf 2 and $\operatorname{orf} 3$ genes and amino acid sequences of their products. Potential-ribosome binding sites (RBS) and putative promotors $(-35,-10$ and +1$)$ are indicated. Stop codons are denoted by asterisks $\left({ }^{*}\right)$ and a potential rhoindependent terminator by converging arrows. Relevant restriction sites are also indicated.

$\left(70{ }^{\circ} \mathrm{C}\right)$. In contrast, only a fraction $(30-40 \%)$ of the fumarase activity in cell-free extracts of $B$. stearothermophilus was oxygen-labile (Fig. 2). Indeed, most of the activity was insensitive to ammonium persulphate and eluted with an apparent $M_{\mathrm{r}}$ of 160000 in gel-filtration, strongly indicating that, like $E$. coli, B. stearothermophilus contains an oxygen-stable (Class II) fumarase as well as an oxygen-labile (Class I) enzyme.

An in vitro transcription-translation analysis (Fig. 3) showed that the three phagemids express a major labelled product $\left(M_{\mathrm{r}} 58000\right)$, presumed to be the fumarase subunit, two minor products $\left(M_{\mathrm{r}} 43000\right.$ and 27000$)$ and $\beta$-lactamase $\left(M_{\mathrm{r}} 30000\right)$. The novel products exceed the coding capacity of the common insert $\left(M_{\mathrm{r}} 100000\right.$ approximately), which could mean that one or both of the minor products are in vitro artefacts or degraded forms of the major product.

\section{Sequence analysis and location of the coding regions}

The complete nucleotide sequence of the common $3 \mathrm{~kb}$ fragment was determined by the strategy summarized in Fig. 1. The sequence (Fig. 4) was fully overlapped and $98 \%$ was derived from both strands. Two complete coding regions were detected using the FRAMESCAN and POSITIONAL BASE PREFERENCES Options of ANALYSEQ 
(Staden, 1984) in conjunction with a codon usage table compiled from the open reading frames detected by Mallinder et al. (1992). The first (coordinates 174 to 1715 ) encodes a product of $M_{\mathrm{r}} 56788$ (514 amino acid residues including formyl-methionine), which corresponds to the major in-vitro-synthesized product. It could be identified as the Class I fumarase of B. stearothermophilus, Fum $\mathrm{A}_{\mathrm{Bs}}$, by virtue of its sequence similarity with FumA and FumB. The second coding region (orf2, coordinates 1842 to 2636) encodes a product of $M_{\mathrm{r}} 30563$ (Orf2, 265 amino acids), which probably corresponds to the in-vitro-synthesized product of $M_{\mathrm{r}}$ 27000 (Fig. 3) and resembles the NodB proteins (see below). There is also an incomplete coding region (orf3) starting at coordinate 2699 and extending for $263 \mathrm{bp}$ to the end sequenced region, but this could not be identified by database searching.

The fum $A_{B s t}$ coding region is preceded by a putative promoter sequence resembling the $\sigma^{70}$ and $\mathrm{E} \sigma^{43}$ promoters of E. coli and B. subtilis (respectively) and a potential ribosome-binding site (Fig. 4). It is followed by a potential stem-loop structure $\left(\Delta G=-89.9 \mathrm{~kJ} \mathrm{~mol}^{-1}\right)$ which could serve as a rho-independent terminator. The start codon (TTG) predicted for orf 2 is not uncommon in Gram-positive bacilli - e.g. B. subtilis argC (Smith et al., 1986) and ger $A$ (Feavers et al., 1990), and B. pumilis cat86 (Harwood et al., 1983) - and it is preceded by a well-placed ribosome-binding site. Neighbouring ATG codons at coordinates 1777, 1822, 1972, 1990 and 2184 (Fig. 4) are not associated with a ribosome-binding site, and in the latter case are situated well downstream of a region of similarity with the NodB proteins (see below). No potential terminator sequences for $\operatorname{orf} 2$, or ribosomebinding sites for $\operatorname{orf} 3$, were detected.

\section{Multiple sequence alignment and detection of two fumA- related genes in E. coli}

In addition to the observed similarities between FumA $A_{\text {Bst }}$ and the FumA and FumB proteins, a database search revealed that OrfZ1 and OrfZ2, the products of adjacent open reading frames located upstream of the $r p s U-$ $d n a G-r p o D$ operon at $67 \mathrm{~min}$ in the $E$. coli linkage map (Nesin et al., 1987) are similar to the respective $\mathrm{N}$ - and Cterminal moieties of the FumA-related proteins. This suggests that OrfZ1 and OrfZ2 combine in forming an iron-sulphur-containing hydratase-dehydratase with an $\alpha_{2} \beta_{2}$ structure like the L-tartrate dehydratase of Pseudomonas putida (Kelly \& Scopes, 1986) or the $(\alpha \beta)_{2}$ structure like 2-hydroxyglutaryl-CoA dehydratase of Acetaminococcus fermentans (Schweiger et al., 1987), rather than the homodimeric $\left(\alpha_{2}\right)$ arrangement in the Class I fumarases.

A multiple sequence alignment for the FumA family is shown in Fig. 5 and an analysis by DISTANCES showed that FumA $\mathrm{A}_{\mathrm{Bst}}$ is slightly closer to the combined OrfZ1/Z2 sequence ( $25 \%$ identity, $45 \%$ similarity) than to FumA $(23 \%, 38 \%)$ and FumB $(23 \%, 37 \%)$, which are themselves remarkably close $(90 \%, 98 \%$; Bell et al., 1989). The Fum ${ }_{\text {Bst }}$ and OrfZ1/Z2 sequences widen the family of FumA-related proteins and draw attention to potentially important residues and motifs which could perform common structural and catalytic roles. Previous comparisons could only be made between the Class I fumarases of $E$. coli (FumA/B) and the potentially analogous iron-sulphur proteins (aconitase, $\mathrm{ACN}$; the iron-responsive-element binding protein, IREBP; and isopropylmalate isomerase, IPMI), and the Class II fumarases and their relatives [aspartase, ASP; argininosuccinase, ARS; and adenylosuccinase, ASL - see Prodromou et al. (1992); Woods et al. $(1988 a, b)$; Aimi et al. (1990)]. The alignment shows that $58(12.7 \%)$ of 457 equivalenced residues are conserved in all of the sequences, including 3 of the 9 or 10 cysteine residues, only 1 of the 11 to 14 histidine residues, and as many as 16 glycine plus proline residues (possibly because the latter residues flank regions of conserved secondary structure).

Cysteine residues generally provide ligands for iron atoms in iron-sulphur proteins via motifs such as $\mathrm{C} x x \mathrm{C} x x \mathrm{C}$ in bacterial ferredoxins or $\mathrm{C} x x \mathrm{C}$ in $\mathrm{ACN}$, where the $[4 \mathrm{Fe}-4 \mathrm{~S}]$ cluster has three cysteine ligands (Robbins \& Stout, 1989a, b). The three conserved cysteine residues, $\mathrm{C}_{62}, \mathrm{C}_{186}$ and $\mathrm{C}_{274}$ at positions 108, 238 and 334 in the alignment (Fig. 5), could presumably perform this function in FumA. Previously, residue $C_{317}$ (position 334) and two residues in the $\mathrm{C} x x \mathrm{C}$ motif near the $\mathrm{C}$-terminus of FumA were proposed as the three iron ligands (Prodromou et al., 1992) but it is now clear that the $\mathrm{C} x x \mathrm{C}$ motif is not conserved in the other FumArelated proteins, FumA $A_{\text {Bst }}$ and OrfZ1/Z2 (Fig. 5).

Only one histidine residue $\left(\mathrm{H}_{396}\right.$ in FumA, position 420 ) is conserved in the alignment (Fig. 5). This residue was identified previously as a potential active-site residue because its context resembles that of an active-site histidine residue in ACN (Prodromou et al., 1992). The similarity extends to aligned sequences in related enzymes, ACN, IREBP and IPMI (Fig. 6a). However, these sequences show no similarity to those containing the sole conserved histidine in the Class II fumarases, ARS and ASL, where there is a GxTH $x x \mathrm{~A}$ consensus (Woods et al., 1988b; Aimi et al., 1990).

There are three conserved lysine residues and two conserved arginine residues in the multiple alignment (Fig. 5) which could provide carboxyl-binding sites. One of the lysine residues $\left(\mathrm{K}_{462}\right.$ in FumA at position 489$)$ is in the only significant sequence motif that is shared by both the FumA (Class I) and FumC (Class II) ASP, ARS and 


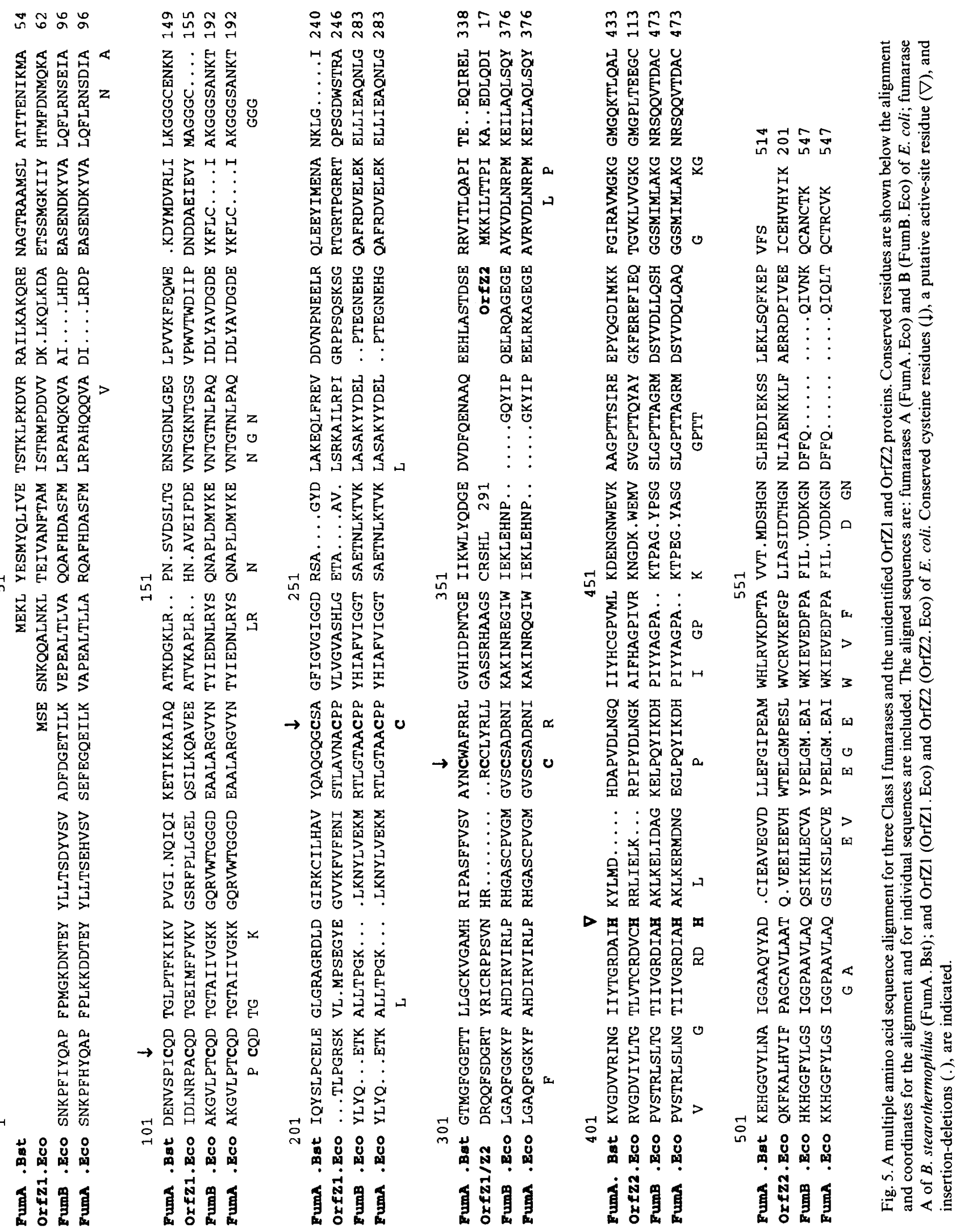


Fig. 6. Sequence similarities between the Fe-Scontaining fumarases and related enzymes. (a) Sequences resembling an active-site histidinyl peptide of porcine aconitase. (b) Sequences containing a motif which is conserved between Class I and Class II fumarases and related enzymes that catalyse $\beta$-elimination reactions yielding fumarate. The sequence sources and abbreviations are as follows: FumA $A_{B s t}$, FumA.Bst; FumA and FumB of E. coli, FumAB. Eco (Miles \& Guest, 1984; Bell et al., 1989); OrfZ2, OrfZ2 . Eco (Nesin et al., 1987); FumC, FumC. Eco (Woods et al., 1986); aspartase, AspA. Eco (Woods et al., 1986); adenylosuccinase, ASL. Eco (He et al., 1992); aconitase, ACN. Eco (Prodromou et al., 1992); porcine heart aconitase, ACN.Por (Zheng et al., 1990); isopropylmalate isomerase, IPMI.Sty (Rosenthal \& Calvo, 1990); human iron-responsive-element binding protein, IREBP. Hum (Rouault et al., 1990); B. subtilis fumarase, CitG.Bsu (Miles \& Guest, 1985); human argininosuccinase, ARS. Hum (Aimi et al., 1990). (a)

FumA . Bst FumAB. Eco OrfZ2. Eco

ACN . ECO ACN . POr IREBP. Hum IPMI . sty
352 390

31

176

141

120

102

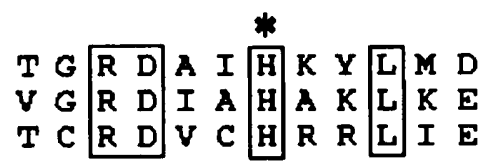

PG TGICHQ $V$ N L E $\begin{array}{llllllllllll}P & G & S & G & I & I & H & Q & I & I & I & E\end{array}$

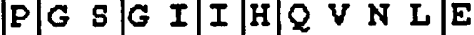

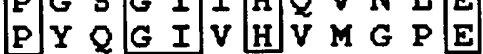

(b)

FumA . Bst

Orfz2.Eco

FumAB, Eco

Citg .Bsu

FumC .Eco

AspA .ECO

ASL .ECO

ARS .Hum

415
95
455

314
316
319
294
280

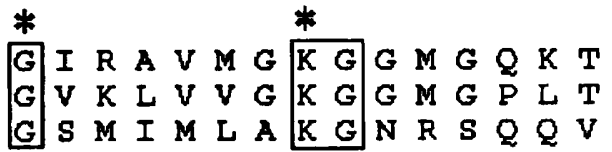

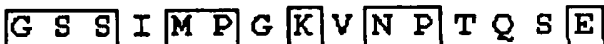
\begin{tabular}{llllll|l|l|l|ll|llll|l}
$G$ & $S$ & $S$ & $I$ & $M$ & $P$ & $A$ & $K$ & $V$ & $N$ & $P$ & $V$ & $V$ & $P$ & $E$
\end{tabular} \begin{tabular}{lll|ll|l|l|l|ll|llll|l}
$G$ & S & S & I & $M$ & P & A & $K$ & $V$ & N & P & $V$ & $V$ & P & E
\end{tabular} \begin{tabular}{llll|ll|l|l|l|ll|lll|l}
$G$ & $S$ & $S$ & $T$ & $M$ & $P$ & $H$ & $K$ & $V$ & $N$ & $P$ & $I$ & $D$ & $F$ & $E$
\end{tabular}

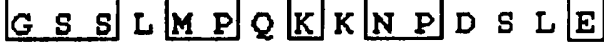

ASL protein families (Fig. $6 b$ ). This motif was originally discovered by Woods et al. $(1988 a, b)$ and later designated as the 'signature sequence' for enzymes which catalyse $\beta$-elimination reactions (Aimi et al., 1990). However, with the inclusion of further sequences, the original GS $x x \mathrm{M} x x \mathrm{~K} x \mathrm{~N}$ consensus has degenerated to $\mathrm{G} x x x x x x \mathrm{~K} x x$, but it still draws attention to a potentially important lysine residue (Fig. 6b). It may also be significant that the leucine and glutamate dehydrogenases contain a conserved lysine residue in a KGGG motif (McPherson et al., 1988; Nagata et al., 1988; Teller et al., 1992) and such a motif occurs at positions 192-195 in the three Class I fumarase sequences (Fig. 5). This motif is not retained in $\operatorname{OrfZ1/Z2,~where~the~substrate~is~}$ unknown, but there are other lysine residues within conserved $\mathrm{KG}$ and $\mathrm{K} x \mathrm{G} / \mathrm{p}$ motifs at positions $489-490$ and 119-121, respectively.

\section{Distribution of the Class I and Class II fumarase genes}

Hybridization probes containing segments of the fumA, fum $_{B s t}$, fumC and citG genes were used with EcoRI digests of bacterial DNA to assess the distribution of the two classes of fumarase in different species by Southern blotting. Identical results were obtained with the two fum $A_{B s t}$ probes shown in Fig. 1, specific hybridization being detected with $B$. stearothermophilus NRRL1174 $(23 \mathrm{~kb})$ and $B$. caldotenax $(9.5 \mathrm{~kb})$ but not with $B$. subtilis 1604 or $E$. coli (Fig. $7 a$ ). No hybridization was detected between the E. coli fumA probe and any of the Bacillus species. Using the cross-hybridizing cit $G$ or fumC probes (Guest et al., 1985), hybridization was detected with $B$. stearothermophilus NRRL1174 $(8 \cdot 8 \mathrm{~kb}), B$. caldotenax $(10 \mathrm{~kb})$ and $B$. stearothermophilus var. non-diastaticus $(4 \cdot 1 \mathrm{~kb})$ (see Fig. $7 b$ for results with the $c i t G$ probe).

These results indicate that the thermophilic bacilli contain a Class I fumarase gene (analogous to fum $A_{B s t}$ ) and a Class II fumarase gene (analogous to the fum $C$ and cit $G$ genes of $E$. coli and B. subtilis). The B. stearothermophilus gene bank is now being screened by hybridization for phages containing fum $C_{B s t}$ DNA since none was recovered by complementation. Despite the absence of hybridization with $B$. subtilis DNA and the lack of fumarase activity in cit $G$ mutants (Rutberg \& Hoch, 1970), it cannot be concluded that $B$. subtilis has no Class I fumarase, because the corresponding $B$. subtilis gene may not hybridize with the fum $A$ probes and an oxygen-labile product may have escaped detection in previous work.

\section{Features of Orf2}

Database searches revealed a significant sequence relationship (21-39\% identity, 39-52\% similarity) between the 211-residue C-terminal segment of Orf2 and the NodB proteins of Rhizobium and Bradyrhizobium (Fig. 8). The precise function of the nodB gene has not been defined but it forms part of the nodABC operon, 
(a)

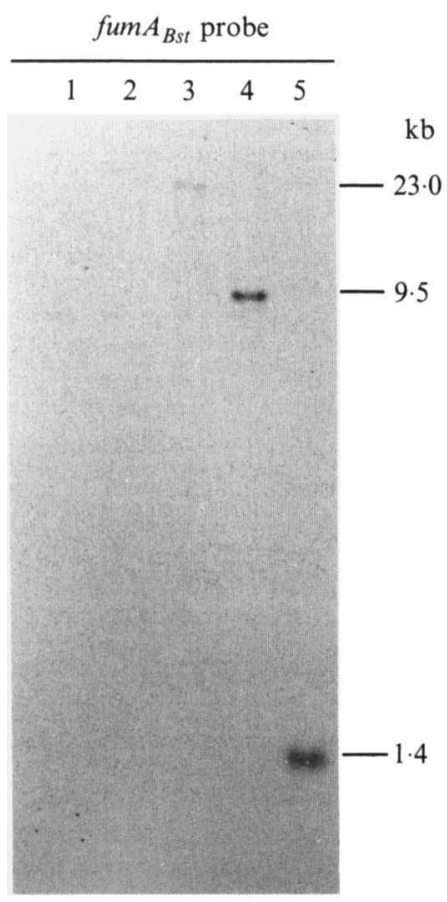

(b)

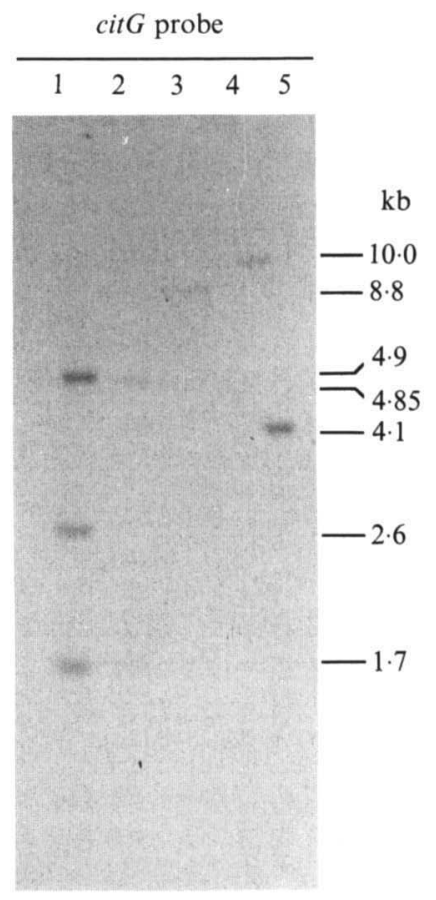

Fig. 7. Southern hybridization of fumA $A_{B s t}$ and citG DNA probes to EcoRI fragments of total DNA from other bacteria. The digoxygenin-labelled probes were (a) fum $A_{B s t}$, F14LH (Fig. 1) and (b) citG from B. subtilis (see Methods), the sizes (kb) of the hybridizing fragments are shown for digests of the following bacteria: $1, B$. subtilis $1604 ; 2, E$. coli W3110; $3, B$. stearothermophilus NRL1174; 4, B. caldotenax DSM406; and 5, B. stearothermophilus var. non-diastaticus.

which is involved in the initiation of root nodulation, possibly by generating signalling molecules that stimulate plant cell mitosis (Downie, 1991; Schmidt et al., 1991; Fisher \& Long, 1992). Compared with the NodB proteins, Orf2 has a 54-residue $\mathrm{N}$-terminal extension possessing some features of a signal peptide over the first 23 residues. It is not clear why $B$. stearothermophilus might express such a protein but further studies might help to define a common role for Orf2 and the NodB proteins in Bacillus and Rhizobium.

\section{Conclusions}

Molecular genetic and biochemical studies have shown that B. stearothermophilus joins E. coli and Bradyrhizobium japonicum (Acuña et al., 1991) in containing two types of fumarase. The fum $A_{B s t}$ gene encoding a Class I fumarase of $B$. stearothermophilus was cloned by nutritional complementation of a fumarase-deficient mutant of $E$. coli, sequenced, and identified by its ability to express an oxygen-labile and thermostable fumarase and by the sequence similarity between FumA $\mathrm{B}_{\mathrm{Bst}}$ and the FumA and FumB enzymes of $E$. coli. Evidence for a Class II fumarase $\left(\right.$ FumC $\left._{\mathrm{Bst}}\right)$ was obtained from enzyme studies and DNA hybridization. The reason why these bacteria possess two classes of fumarase is not clear but recent studies with $E$. coli indicate that fumC belongs to the sox $R$ modulon (Liochev \& Fridowich, 1992). The sox $R$ regulatory system operates during oxidative stress to maintain cellular redox balance and normal metabolic flux, and this would be favoured by replacing the unstable FumA by FumC. In contrast, fumA is a member of the $\operatorname{arc} A$ and $\operatorname{crp}$ modulons, i.e. subject to aerobic respiratory control and catabolite repression, whereas fumB is subject to anaerobic repression and belongs to the fnr modulon (Woods \& Guest, 1987; Guest \& Russell, 1992).

Database searches revealed significant similarity between the Class I fumarases and the products, OrfZ1 and OrfZ2, of two adjacent $E$. coli genes, indicating that the latter combine to form an oxygen-labile, iron-sulphurcontaining hydratase-dehydratase. Work is now in progress to isolate the fum $C_{B s t}$ gene and to characterize the OrfZ1/Z2 enzyme. Putative active-site residues and structural motifs were detected by sequence comparisons with aconitase, isopropylmalate isomerase and other related enzymes. B. stearothermophilus was also shown to contain a gene that resembles the $\operatorname{nodB}$ genes of Rhizobium and Bradyrhizobium where it is essential for the initiation of root nodulation. 


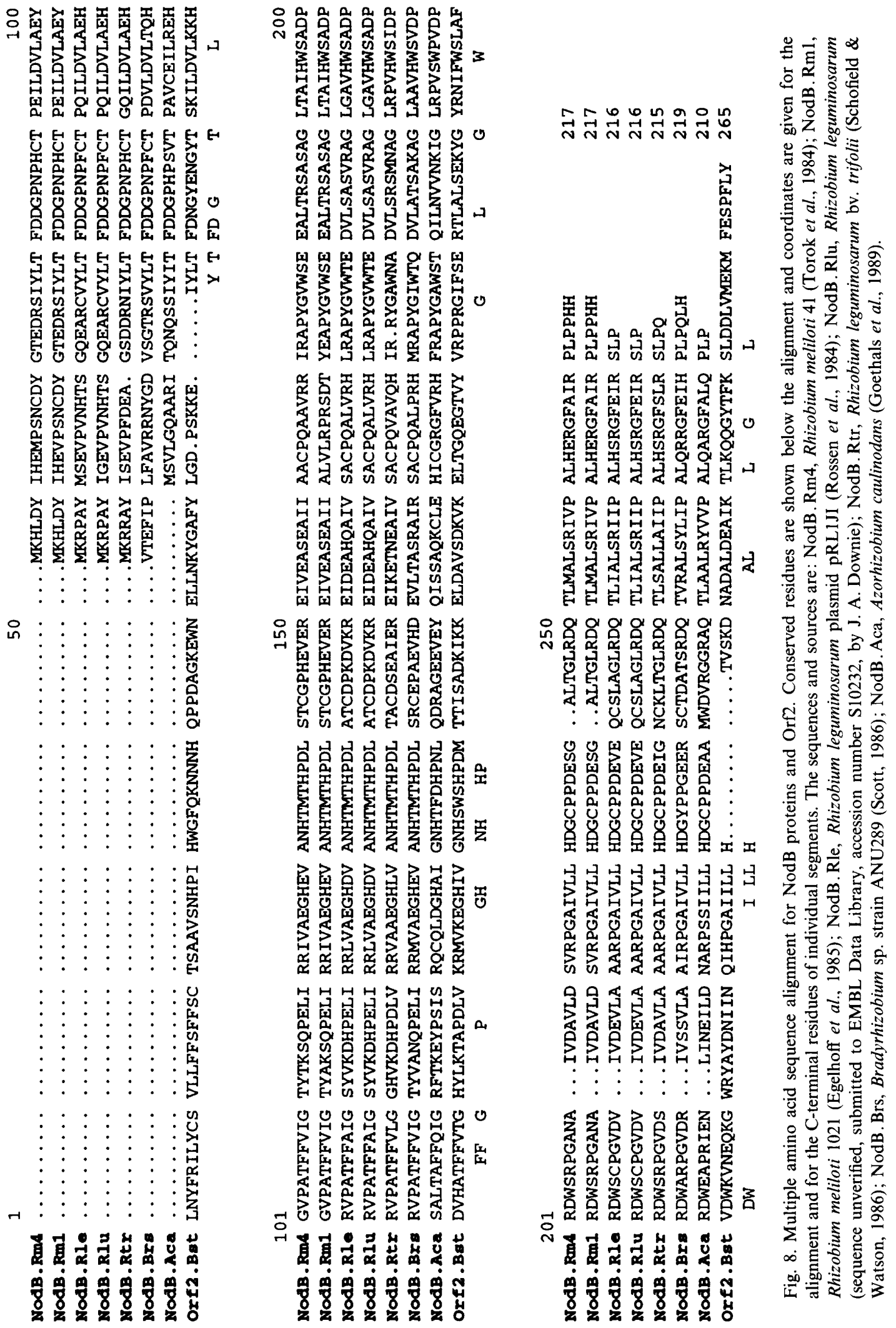


We are very grateful to P. R. Mallinder, A. Moir, S. C. Andrews and C. Prodromou for helpful advice and materials. The work was supported by a SERC-CASE studentship (S.K.R.) with ICI BioProducts and Fine Chemicals.

\section{References}

Acuña, G., Ebeling, S. \& HenNeCKe, H. (1991). Cloning, sequencing, and mutational analysis of the Bradyrhizobium japonicum fumC-like gene: evidence for the existence of two different fumarases. Journal of General Microbiology 137, 991-1000.

Aimi, J., Badylak, J., Williams, J., Chen, Z., Zalkin, H. \& Dixon, J. E. (1990). Cloning of a cDNA encoding adenylosuccinate lyase by functional complementation in Escherichia coli. Journal of Biological Chemistry 265, 9011-9014.

Bell, P. J., Andrews, S. C., Sivak, M. N. \& Guest, J. R. (1989). Nucleotide sequence of the FNR-regulated fumarase gene (fumB) of Escherichia coli K12. Journal of Bacteriology 171, 3494-3503.

BRADFORD, M. M. (1976). A rapid and sensitive method for the quantitation of microgram quantities of protein utilizing the principle of protein dye-binding. Analytical Biochemistry 72, 248-253.

BuCKEL, W. (1992). Unusual dehydrations in anaerobic bacteria. FEMS Microbiology Reviews 88, 211-232.

Bullock, W. O., Fernandez, J. M. \& Shor T, J. M. (1987). XL1-Blue: A high efficiency plasmid transforming recA Escherichia coli strain with $\beta$-galactosidase selection. Biotechniques 5, 376-379.

CAMmaCK, R. (1991). Iron-sulphur clusters in enzymes - themes and variations. Advances in Organic Chemistry 38, 1-24.

Cole, S. T. \& GuEST, J. R. (1980). Genetic and physical characterization of lambda transducing phages $(\lambda f r d A)$ containing the fumarate reductase gene of Escherichia coli K12. Molecular and General Genetics 178, 409-418.

DevereuX, J., Haeberli, P. \& Smithies, O. (1984). A comprehensive set of sequence-analysis programs for the VAX. Nucleic Acids Research 12, 387-395.

DownIE, A. (1991). A nod of recognition. Current Biology 1, 382-384.

Egelhoff, T. T., Fisher, R. F., JACOBS, T. W., Mulligan, J. T. \& LONG, S. R. (1985). Nucleotide sequence of Rhizobium meliloti 1021 nodulation genes: nodD is read divergently from nodABC. DNA 4, 241-248.

Feavers, I. M., Foulkes, J., Setlow, B., Sun, D., Nicholson, W., Setrow, P. \& Molr, A. (1990). The regulation of the ger A spore germination operon of Bacillus subtilis. Molecular Microbiology 4, 275-282.

FisHER, R. F. \& LONG, S. R. (1992). Rhizobium-plant signal exchange. Nature, London 357, 655-660.

Flint, D. H., Emptage, M. H. \& Guest, J. R. (1989). Fumarase A from $E$. coli contains a [4Fe-4S] cluster. Journal of Inorganic Biochemistry 36, 306.

Funt, D. H., EmptaGe, M. H. \& Guest, J. R. (1989). Fumarase A from Escherichia coli: purification and characterization as an iron-sulfur cluster containing enzyme. Biochemistry 31, 10331-10337.

Goethals, K., GaO, M., Tomekpe, K., Van Montagu, M. \& Holsters, M. (1989). Common nodABC genes in NodW locus 1 of Azorhizobium caulinodans: nucleotide sequence and plant inducible expression. Molecular and General Genetics 219, 289-298.

GuEST, J. R. \& RoBerTS, R. E. (1983). Cloning, mapping and expression of the fumarase gene of Escherichia coli K-12. Journal of Bacteriology 153, 588-596.

Guest, J. R. \& Russell, G. C. (1992). Complexes and complexities of the citric acid cycle in Escherichia coli. Current Topics in Cellular Regulation 33, 231-247.

Guest, J. R., Miles, J. S., Roberts, R. E. \& Woods, S. A. (1985). The fumarase genes of Escherichia coli: location of the fumB gene and discovery of a new gene (fumC). Journal of General Microbiology 131, 2971-2984.

Guest, J. R. Green, J., Spiro, S., Prodromou, C. \& Sharrocks, A. D. (1990). Regulation of gene expression by oxygen in Escherichia coli. In The Molecular Basis of Bacterial Metabolism, pp. 134-145. Edited by G. Hauska \& R. Thauer. Berlin: Springer-Verlag.
HaRwood, C. R., Williams, D. M. \& LovetT, P. S. (1983). Nucleotide sequence of a Bacillus pumilis gene specifying chloramphenicol acetyltransferase. Gene 24, 163-169.

HE, B., SMITH, J. M. \& ZALKIN, H. (1992). Escherichia coli purB gene: nucleotide sequence and regulation by purR. Journal of Bacteriology 174, 130-136.

Henson, J. M., Blake, N. K. \& Marek, L. (1987). The isolation of fumB mutants of Escherichia coli. Journal of General Microbiology 133, 2631-2638.

Higgins, D. G. \& Sharp, P. M. (1988). Clustal: a package for performing multiple sequence alignments on a microcomputer. Gene $73,237-244$.

Higgins, D. G. \& Sharp, P. M. (1989). Fast and sensitive multiple sequence alignments on a microcomputer. Cabios 5, 151-153.

Hill, R. L. \& Bradshaw, R. A. (1969). Fumarase. Methods in Enzymology 13, 91-99.

KELLY, J. M. \& SCOPES, R. K. (1986). L-(+)-Tartrate dehydratase from Pseudomonas putida is an iron-sulphur enzyme. FEBS Letters 202 274-276.

KinSElla, T. R. \& Doonan, S. (1986). Nucleotide sequence of a cDNA coding for mitochondrial fumarase from human liver. Bioscience Reports 6, 921-929.

LAEMMLI, U. K. (1970). Cleavage of structural proteins during the assembly of the head of bacteriophage T4. Nature, London 227, 680-685.

LiaO, H., McKenzie, T. \& Hageman, R. (1986). Isolation of a thermostable enzyme variant by cloning and selection in a thermophile. Proceedings of the National Academy of Sciences of the United States of America 83, 576-580.

LIOCHEV, S. I. \& Fridovich, I. (1992). Fumarase C, the stable fumarase of Escherichia coli, is controlled by the soxRS regulon. Proceedings of the National Academy of Sciences of the United States of America 89, 5892-5896.

Mallinder, P. R., Pritchard, A. \& Moir, A. (1992). Cloning and characterization of a gene from Bacillus stearothermophilus var. nondiastaticus encoding a glycerol dehydrogenase. Gene 110, 916.

McPherson, M. J., Baron, A. J., Jones, K. M., Price, G. J. \& Wootron, J. C. (1988). Multiple interactions of lysine-128 of Escherichia coli glutamate dehydrogenase revealed by site-directed mutagenesis studies. Protein Engineering 2, 147-152.

MiLES, J. S. \& GUEST, J. R. (1984). Complete nucleotide sequence of the fumarase gene fumA of Escherichia coli. Nucleic Acids Research 12, 3631-3642.

MiLES, J. S. \& GuEST, J. R. (1985). Complete nucleotide sequence of the fumarase gene (citG) of Bacillus subtilis 168. Nucleic Acids Research $13,131-140$

Messing, J. (1983). New M13 vectors for cloning. Methods in Enzymology 101, 20-78.

MorR, A. (1983). The isolation of lambda transducing phages carrying the citG and gerA genes of Bacillus subtilis. Journal of General Microbiology 129, 303-310.

MoIR, A., LAFFerTy, E. \& SMith, D. A. (1979). Genetic analysis of spore germination mutants of Bacillus subtilis 168: the correlation of phenotype with map location. Journal of General Microbiology 111, $165-180$.

Moir, A., Feavers, I. M. \& Guest, J. R. (1984). Characterization of the fumarase gene of Bacillus subtilis 168 cloned and expressed in Escherichia coli K12. Journal of General Microbiology 130, 3009-3017.

Nagata, S., Tanizawa, K., Esaki, N., Sakamoto, Y., Oshima, T., TANAKA, H. \& SODA, K. (1988). Gene cloning and sequence determination of leucine dehydrogenase from Bacillus stearothermophilus and structural comparisons with other NAD $(\mathrm{P})^{+}$-dependent dehydrogenases. Biochemistry 27, 9056-9062.

Nesin, M., LuPSKı, J. R., Svec, P. \& Godson, G. N. (1987). Possible new genes as revealed by molecular analysis of a 5-kb Escherichia coli chromosomal region $5^{\prime}$ to the $r p s U-d n a G-r p o D$ macromolecularsynthesis operon. Gene 51, 149-161.

Prodromou, C., Artymiuk, P. J. \& Guest, J. R. (1992). The aconitase of Escherichia coli: nucleotide sequence of the aconitase gene and amino acid sequence similarity with mitochondrial aconitases, the 
iron-responsive-element-binding protein and isopropylmalate isomerases. European Journal of Biochemistry 204, 599-609.

Robiins, A. H. \& Stout, C. D. (1989a). The structure of aconitase. Proteins 5, 289-312.

Robiins, A. H. \& Stout, C. D. (1989b). Structure of activated aconitase: formation of the [4Fe-4S] cluster in the crystal. Proceedings of the National Academy of Sciences of the United States of America 86, 3639-3643.

Rosenthal, E. R. \& Calvo, J. M. (1990). The nucleotide sequence of leuC from Salmonella typhimurium. Nucleic Acids Research 18, 3072.

Rossen, L., Johnston, A. W. B. \& Downie, J. A. (1984). DNA sequence of the Rhizobium leguminosarum nodulation genes nodAB and $C$ required for root hair curling. Nucleic Acids Research 12, 9497-9508.

Rouault, T. A., Tang, C. K., Kaptain, S., Burgess, W. H., Haile, D. J., Samaniego, F., McBride, W., Harford, J. B. \& Klausner, R. D. (1990). Cloning of the cDNA encoding an RNA regulatory protein - the human iron-responsive element-binding protein. Proceedings of the National Academy of Sciences of the United States of America 87, 7958-7962.

RutBerg, B. \& Hoch, J. A. (1970). Citric acid cycle: gene-enzyme relationships in Bacillus subtilis. Journal of Bacteriology 104, 826-833.

Sachettini, J. C., Frazier, M. W., Chiara, D. C., Banaszak, L. J. \& Grant, G. A. (1988). Amino acid sequence of porcine heart fumarase. Biochemical and Biophysical Research Communications $153,435-440$.

SambrooK, J., Fritsch, E. F. \& Maniatis, T. (1989). Molecular Cloning: a Laboratory Manual, 2nd edn. Cold Spring Harbor, NY: Cold Spring Harbor Laboratory.

Schmidt, J., John, M., Kondorosi, E. Kondorosi, A. \& Schell, J. (1991). Recent progress in the elucidation of the function of nod $A, B$ and $C$ genes of Rhizobium meliloti. Israel Journal of Botany 40, $165-169$.

Schofield, P. R. \& WATSON, J. M. (1986). DNA sequence of Rhizobium trifolii nodulation genes reveals a reiterated and potentially regulatory sequence preceding nodABC and nodFE. Nucleic Acids Research 14, 2891-2903.

SChweiger, G., Dutscho, R. \& Buckel, W. (1987). Purification of 2hydroxyglutaryl-CoA dehydratase from Acidaminococcus fermentans: an iron-sulfur protein. European Journal of Biochemistry 169, $441-448$.

ScotT, K. (1986). Conserved nodulation gene from the non-legume symbiont Bradyrhizobium sp. (Parasponia). Nucleic Acids Research 14, 2905-2919.

Sharp, R. J., Ahmad, S. I., Munster, A., Dowsett, B. \& Atkinson, T. (1986). The isolation and characterization of bacteriophages infecting obligately thermophilic strains of Bacillus. Journal of General Microbiology 132, 1709-1722.

Shibata, H., Gardiner, W. E. \& Schwartzbach, S. D. (1985). Purification, characterization, and immunological properties of fumarase from Euglena gracilis var. bacillaris. Journal of Bacteriology 164, 762-768.

Smith, M. C. M., Mountain, A. \& Baumberg, S. (1986). Sequence analysis of the Bacillus subtilis argC promoter region. Gene 49, 53-60.
Staden, R. (1980). A new computer method for the storage and manipulation of DNA gel reading data. Nucleic Acids Research 8, 3673-3694.

STADEN, R. (1982). An interactive graphics program for comparing and aligning nucleic acid and amino acid sequences. Nucleic Acids Research 10, 2951-2961.

Staden, R. (1984). Graphic methods to determine the function of nucleic acid sequences. A summary of ANALYSEQ options. Nucleic Acids Research 12, 505-519.

Staden, R. \& MCLACHLAN, A. D. (1982). Codon preference and its use in identifying protein coding regions in long DNA sequences. Nucleic Acids Research 10, 141-156.

Suzuki, T., Sato, M., Yoshida, T. \& Tubol, S. (1989). Rat liver mitochondrial and cytosolic fumarases with identical amino acid sequences are encoded from a single gene. Journal of Biological Chemistry 264, 2581-2586.

SWITZER, R. L. (1989). Non-redox roles for iron-sulfur clusters in enzymes. Biofactors 2, 77-86.

Teller, J. K., Smith, R. J., McPherson, M. J., Engel, P. C. \& Guest, J. R. (1992). The glutamate dehydrogenase of Clostridium symbiosum: cloning by polymerase chain reaction, sequence analysis and over-expression in Escherichia coli. European Journal of Biochemistry 206, 151-159

ToroK, I., Kondorosi, E., Stepkowski, T., Posfai, J. \& Kondorosi, A. K. (1984). Nucleotide sequence of Rhizobium meliloti nodulation genes. Nucleic Acids Research 12, 9509-9522.

Ueda, Y., Yumoto, N., Tokushige, M., Fukui, K. \& OhyaNishiguchI, H. (1991). Purification and characterization of two types of fumarase from Escherichia coli. Journal of Biochemistry 109. 728-733.

Woods, S. A. \& Guest, J. R. (1987). Differential roles of the Escherichia coli fumarases and $f n r$-dependent expression of fumarase B and aspartase. FEMS Microbiology Letters 48, 219-224.

Woods, S. A., Miles, J. S., Roberts, R. E. \& Guest, J. R. (1986). Structural and functional relationships between fumarase and aspartase. Biochemical Journal 237, 547-557.

Woods, S. A., Schwartzbach, S. D. \& Guest, J. R. (1988a). Two biochemically distinct classes of fumarase in Escherichia coli. Biochimica et Biophysica Acta 954, 14-26.

Woods, S. A., Miles, J. S. \& Guest, J. R. (1988b). Sequence homologies between arginosuccinase, aspartase and fumarase: a family of structurally-related enzymes. FEMS Microbiology Letters 51, 181-186.

Wu, M. \& Tzagoloff, A. (1987). Mitochondrial and cytoplasmic fumarases in Saccharomyces cerevisiae are encoded by a single nuclear gene FUM1. Journal of Biological Chemistry 262, $12275-12282$.

Yumoto, N. \& Tokushige, M. (1988). Characterization of multiple fumarase proteins in Escherichia coli. Biochemical and Biophysical Research Communications 153, 1236-1243.

Zheng, L., Andrews, P. C., Hermodson, M. A., Dixon, J. E. \& ZALKIN, H. (1990). Cloning and structural characterization of porcine heart aconitase. Journal of Biological Chemistry 265, 2814-2821. 